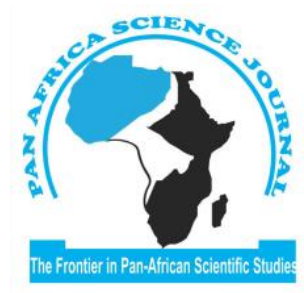

Pan Africa Science Journal

ISSN 2709-1473 | Open Access

\title{
Abundance, diversity and distribution of Macrophytes in lotic wetlands: A case study on Sironga and Kapkatet Wetlands, Kenya
}

\author{
Angima Merceline ${ }^{1 *}$, Akama John², Omondi Argwings ${ }^{3}$, Omweno Job ${ }^{1}$, Mungai Dan ${ }^{4}$ \\ ${ }^{1}$ Department of Natural Resources and Aquatic Sciences, Kisii University, P.O Box 408-40200, Kisii, Kenya. \\ ${ }^{2}$ Ecotourism and African Heritage, Kisii University, P.O Box 408-40200, Kisii, Kenya Department of \\ ${ }^{3}$ Department of Medical and Applied Sciences, Sigalagala National Polytechnic, P.O Box 2966-50100, Kakamega \\ ${ }^{4}$ National Aquaculture Research Development \& Training Centre, Sagana Fisheries \\ * Corresponding author: mangima@kisiiuniversity.ac.ke
}

Received: $5^{\text {th }}$ January 2022; Accepted: $9^{\text {th }}$ February 2022; Published: $11^{\text {th }}$ February 2022 DOI: $10.47787 /$ pasj.v1i02.11

\begin{abstract}
Wetland macrophytes provide important ecological and social-economic values. However, the recent increase in anthropogenic influences has compromised the ecological integrity of most lotic wetlands, which has ultimately threatened their structure and functioning, causing degradation and loss of macrophytes. This study was aimed at assessing the biodiversity, distribution and abundance of macrophytes in Sironga and Kapkatet wetlands with respect to various anthropogenic activities. Sampling was conducted for a period of six months, covering both dry and wet seasons from February July 2019. Macrophytes were identified using identification keys and diversity indices such as the Shannon-Wiener, Simpson's, and Species evenness were used to determine macrophyte diversities. The numbers of different macrophytes species was enumerated from five randomly sampled line transects along the water ways and another fifteen also randomly distributed on the wetlands on a monthly basis. There were three main lifeforms of aquatic macrophytes found in both Sironga and Kapaktet wetlands namely, emerged, submerged and floating, which were dominated by Centella asciatica and Cyperus sp. and the floating macrophytes, Potamogeton schwenfurthii dominated Kapaktet wetland. The study found that macrophyte distribution, abundance and biodiversity were highly affected by predominant economic activities resulting to wetland conversion, nutrient influxes and unsustainable exploitation of macrophytes. We recommend a further study focusing on effects of sedimentation resulting from unsustainable agricultural practices on water quality and macrophytes diversity, distribution and abundance, the effects of changing land-use practices and how different environmental agencies can be involved in the advocacy, conservation and management of the riverine wetlands.
\end{abstract}

Keywords: Lotic Wetlands; Macrophytes; Diversity; Distribution; Abundance 


\section{INTRODUCTION}

On an ecological perspective, wetlands are highly diverse ecosystems which are seasonally or permanently inundated with water. This provides anoxic conditions that support oxygen-free processes, which promote the growth of characteristically distinct wetland vegetation [1]. These plants co-exist in most wetlands, some such as the free floating macrophytes, such as Pistia stratiotes and Eichhornia crassipes which have a short turnover time being extensively used in constructed wetlands to remove nutrients and heavy metals like Zinc, Nikel, and Cadmium from wastewater [2]. According to the Ramsar convention of 1971, wetlands occur naturally or artificially, lotic or lentic, some are seasonal while others occur permanently [7, 8, 9]. Although wetlands only cover approximately $6 \%$ of earth's surface, their immense value is largely underestimated, owing to their multiple ecological and economic uses [3]. Different life forms of wetlands such as the floating-leaved macrophytes are secondary carbon sources which biogeochemically transfer energy to the decomposers. Additionally, plant surfaces provide habitat for bacterial growth, as well as uptake and storage of the nutrients and aeration of water bodies [4]. Population growth has nonetheless fueled increased utilization of macrophytes threatening different species with total extinction. This is because water quality in these wetlands is highly compromised by pollution, abstraction and wetland conversion which can result into low biodiversity and decreased importance of wetlands with regard to sustenance of life on earth [5].

Due to the recent growth of anthropogenic influence on natural ecosystems, it is difficult to achieve a well-balanced wetland ecosystem without adequate conservation measures which are geared towards restoration of ecosystem integrity, economic and aesthetic values of wetlands. Therefore, maintenance of healthy and diverse wetland ecosystem is crucial to ensure balanced 
biotic and abiotic interactions [6]. The abundance, occurrence, composition, distribution and biodiversity of aquatic macrophytes depends on many factors, such as availability of solar energy which is converted to organic matter, wetland processes and energy dynamics as well as physico-chemical parameters of the wetland environment [10, 11, 12, 13]. For instance, countries which lie within the tropics have a high abundance, distribution and diversity of aquatic macrophytes probably because of a constant photoperiod and Papyrus spp. is among the most dominant and most productive emergent macrophytes in the tropical and subtropical regions $[6,12,13]$. In Kenya, some fringe riverine and lacustrine wetlands are commonly known as "Papyrus wetlands" due to extensive distribution and abundance of different Papyrus spp. Despite the important salient characteristics, socio-economic and ecological values of wetlands, there is paucity of information on macrophyte characteristics of most Kenyan wetlands [14]. This study therefore aimed at assessing the distribution, abundance and diversity of macrophytes in Sironga and Kapkatet wetlands which provide water sources to feed influent rivers draining into Lake Victoria.

\section{MATERIALS AND METHODS}

\subsection{Study areas}

Sironga $\left(00^{\circ} 30^{\prime} 23^{\prime \prime} \mathrm{S}, 34^{\circ} 54^{\prime} 58^{\prime \prime}\right.$ E) and Kapkatet $\left(0^{\circ} 38^{\prime} 32^{\prime \prime} \mathrm{S}, 35^{\circ} 13^{\prime} 21^{\prime \prime}\right.$ E) wetlands, are Kenyan highland wetlands located at altitudes of 2,017 and 1,957 meters in Nyamira and Kericho Counties respectively (Fig. 1 \& Fig. 2). The two wetlands are approximately $30 \mathrm{~km}$ apart located in a densely populated region of about 900 people per $\mathrm{km} 2$ and the sampling sites were selected based on varied human activities within the Wetlands. 


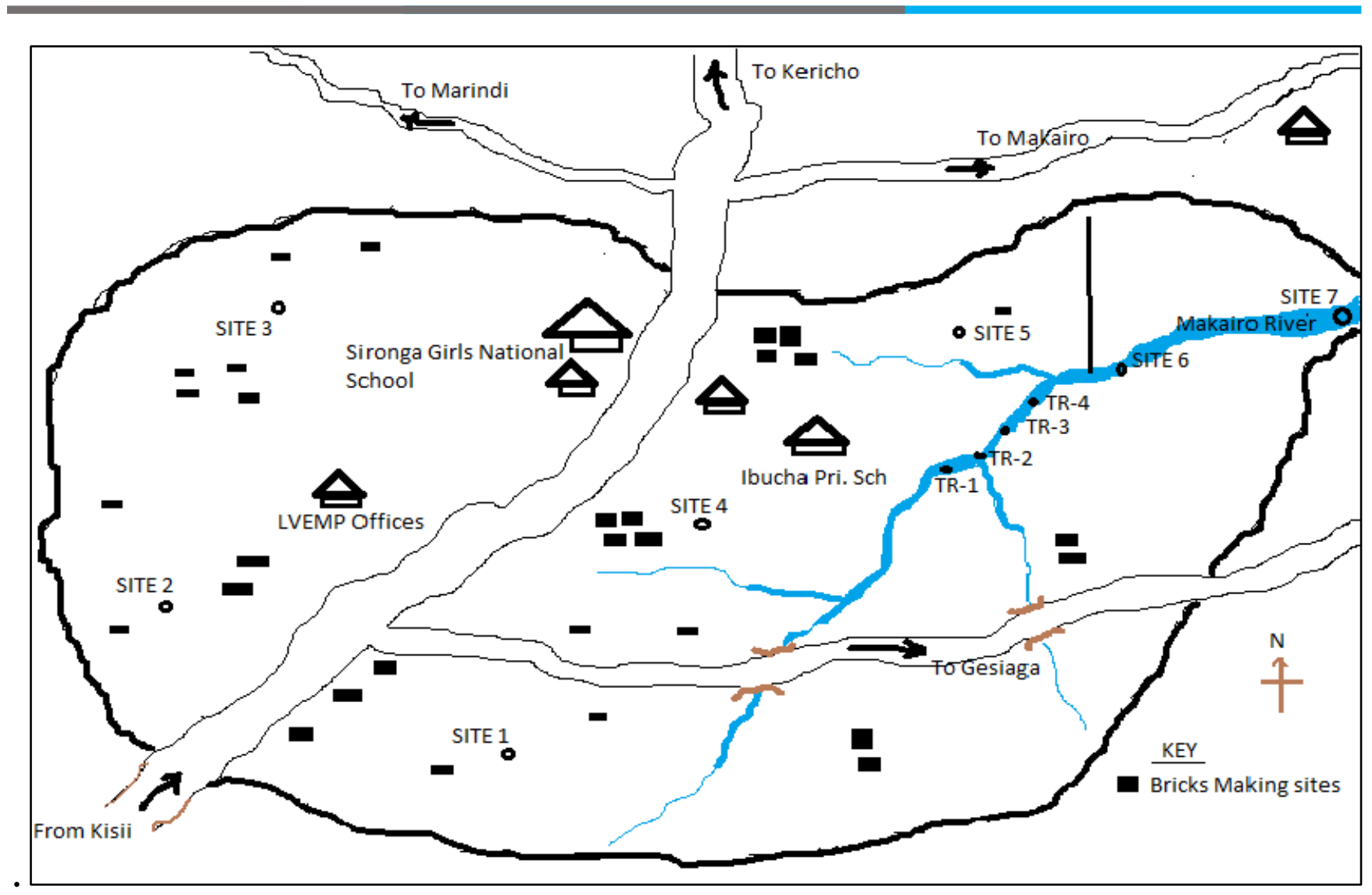

Figure 1: A sketch Map Showing the Sironga Wetland and some human activities within and around it

In both wetlands, the sampling sites were selected based on the predominant human activities. For instance site G1 (0.35490S, $0.3454420 \mathrm{E})$ was conspicuously affected by water abstraction for car wash and infrastructural development such as road and building construction, whereas, site $\mathrm{T} 1(00.6008680 \mathrm{~S}, 034.9110120 \mathrm{E})$ was a recipient of the effects of farming activities in the wetland. The predominant economic activity in site W1was brick making and indiginous riparian vegetation had been replaced by exotic Eucalyptus spp. On the other hand, site W2 (00.5958400S, 034.9120920E) was mainly used for grazing animals. For Kapkatet wetland, selection of Site S1 (00.6511950S, 035.2089720E) in Kapkatet wetland was premised on the recent increase in agricultural activities, while sites S2 (00.6500930S, 035.2060380E) and S3 were to cover the effects 
of wetland conversion (into padocking and Eucalyptus plantation) and infrastructural development respectively.

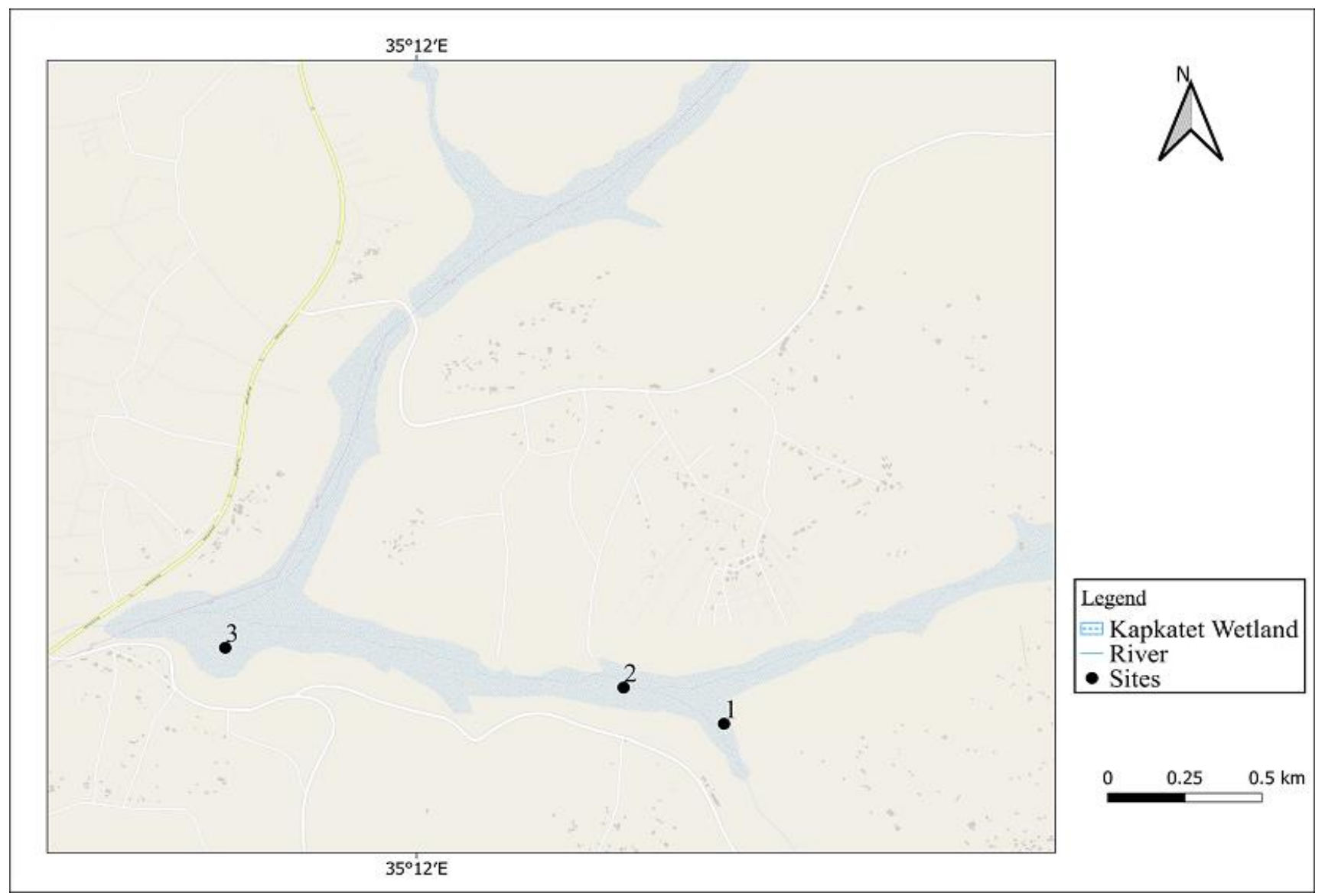

Figure 2: Map of Kapkatet wetland showing sampling sites in Kericho County

\subsection{Sampling of Macrophytes}

A Global Positioning System (model 35c-Garmin) was used to map the randomly selected sampling sites. Various macrophytes were collected from these sites for identification, enumeration and classification. Macrophyte samples from different sampling sites were sampled using 5 by $5 \mathrm{~m}$ quadrats and $50 \mathrm{~m}$ long line transects for which all the macrophytes were 
counted and then the procedure was repeated for the remaining 19 points. From that, 5 and 15 randomly distributed line-transects were used to sample the riparian zone and extensive floodplain respectively on a monthly basis for a period of six months. The different plants were counted and identification of different macrophytes was done to species level through visual observation of plant morphological features, such as flowers, fruits, shoot and rhizomes [14, 15, 16]. The percentage cover of macrophytes was estimated using photographs taken during sampling. The macrophyte plants collected were labeled and stored correctly to avoid damaging plant morphological features such as flowers, fruits and rhizomes which provide a brief description of the habitat.

\subsection{Estimation of Biodiversity indices}

The study estimated four diversity indices according to [17]: Shannon-Wiener $(H)=\sum-(P i *$ $\ln \mathrm{Pi}$ ), where; $\boldsymbol{\Sigma}$ is the sum of all calculation and $\mathbf{P}_{\mathbf{i}}$ is the fraction of species $\mathrm{i}$ in the entire

population while Simpson's diversity index: $(\boldsymbol{D})=\frac{\sum n(n-1)}{N(N-1)}$, where; $\mathbf{n}=$ number of individuals of each species and $\mathbf{N}$, the total number of individuals of all species. Species richness $=\frac{S}{\sqrt{N}}$ where $\mathbf{S}$ is the number of species and $\mathbf{N}$ the total number of individuals of all species and species evenness $=(\boldsymbol{E})=\mathbf{1}-\frac{\boldsymbol{I m i n}}{\boldsymbol{I m a x}-\boldsymbol{I} \boldsymbol{m i n}}$ where $\mathbf{I}$ is the diversity index and $I_{\min }$ and $I_{\max }$, the lowest and highest values of this index for the given number of species.

\section{RESULTS}

Throughout the study, a total number of 21900 aquatic plants of different categories (emergent, sub- merged, floating and free floating) were collected, consisting of 53 species of macrophytes that were identified from all seven sampling stations (Table 1). The aquatic macrophytes represented 21 families. The highest dominated were Centella asiatica, Cyperus helferi and C. marginatus, the least dominant was Kolanchoe densifora. Centella asiatica, Limnophila chinensis, 
Isolepsis fruitans and Cyperus sp. were evenly distributed in all sampling sites. Majority of the species were found in site S1 in Kapkatet wetland and the least were found in site T1 in Sironga wetland. Macrophytes richness changed with time and area. C. asiatica recorded higher density in S1 of 1050 followed by W2 with 650 while S3 recorded lower density of 200. C. helferi and C. marginatus recorded a higher density in S1 of 1100 and 1055 respectively. Polygonum setosulum, Kolanchoe densiflora, Polygonum sp., Teramnus sp, Dichrocephala sp, Alchemilla sp, Osmondia regalis, Dissotis sp and Sphaeranthus suaveolens recorded low densities in all the sampling sites.

Table 1: Macrophytes distribution in Sironga and Kapkatet wetlands

\begin{tabular}{llllllll}
\hline Botanical name & G1 & T1 & W1 & W2 & S1 & S2 & S3 \\
\hline Centella asiatica & 300 & 0 & 600 & 650 & 1050 & 500 & 200 \\
Blechum indicum & 10 & 0 & 12 & 0 & 22 & 0 & 0 \\
Athyrium filix- femina & 15 & 0 & 20 & 0 & 25 & 18 & 0 \\
Aciotis acuminifolia & 10 & 0 & 50 & 0 & 0 & 0 & 0 \\
Limnophila chinensis & 0 & 0 & 150 & 0 & 0 & 0 & 0 \\
Cyperus helferi & 100 & 0 & 254 & 0 & 1100 & 450 & 278 \\
Comarum palustre & 0 & 0 & 210 & 150 & 750 & 0 & 0 \\
Cyperus marginatus & 100 & 0 & 254 & 0 & 1055 & 250 & 138 \\
Actinoscirpus grossus & 0 & 0 & 210 & 150 & 750 & 0 & 0 \\
Colocasia esculenta & 0 & 0 & 0 & 0 & 0 & 0 & 150 \\
Cyperus rotundus & 0 & 0 & 115 & 150 & 750 & 320 & 0 \\
Panicum virgatum & 158 & 0 & 0 & 0 & 372 & 120 & 0 \\
Robus apetalus & 0 & 0 & 120 & 0 & 350 & 0 & 0 \\
Ludwiga abyssinica & 17 & 0 & 0 & 0 & 167 & 0 & 0 \\
Polygonum setosulum & 58 & 0 & 0 & 0 & 0 & 0 & 0 \\
Coelachne Africana & 210 & 0 & 320 & 0 & 0 & 0 & 0
\end{tabular}




\begin{tabular}{|c|c|c|c|c|c|c|c|}
\hline Helichrysum forskahlii & 0 & 0 & 0 & 0 & 392 & 0 & 0 \\
\hline Crassula granuikii & 195 & 120 & 155 & 0 & 558 & 215 & 0 \\
\hline Dissotis senegambieceaesis & 0 & 0 & 0 & 0 & 298 & 0 & 0 \\
\hline Sphaeranthus suaveolens & 0 & 45 & 0 & 0 & 0 & 0 & 0 \\
\hline Isolepis fruitans & 120 & 95 & 152 & 108 & 225 & 120 & 108 \\
\hline Helichrysum globosum & 0 & 0 & 0 & 0 & 165 & 0 & 0 \\
\hline Commelina diffusa & 0 & 0 & 0 & 0 & 0 & 118 & 0 \\
\hline Plectrathus punctatus & 0 & 0 & 0 & 0 & 258 & 0 & 0 \\
\hline Pennisetum clandestinum & 0 & 0 & 185 & 0 & 250 & 0 & 0 \\
\hline Melanthera scandens & 0 & 0 & 0 & 0 & 185 & 0 & 0 \\
\hline Pellacavindis varocanonica & 22 & 0 & 0 & 0 & 0 & 0 & 0 \\
\hline Alchemilla kiwawensis & 20 & 15 & 0 & 0 & 171 & 62 & 0 \\
\hline Polygonum nepalense & & 0 & & & 0 & 66 & 0 \\
\hline Spermacoce princiae & 0 & 0 & 0 & 0 & 0 & 51 & 0 \\
\hline Digitaria abyssinica & 121 & 85 & 181 & 175 & 0 & 0 & 0 \\
\hline Tristema mauritianum & 7 & 0 & 27 & 15 & 0 & 0 & 0 \\
\hline Poa annua & 227 & 0 & 315 & 0 & 0 & 0 & 0 \\
\hline Kolanchoe densiflora & 0 & 0 & 0 & 0 & 17 & 0 & 0 \\
\hline Cyphostempm barbuseti & 0 & 0 & & 0 & 62 & 0 & 0 \\
\hline Achyrospermum schimperi & 18 & 0 & 0 & 0 & 75 & 0 & 0 \\
\hline Polygonum salicifolium & 38 & 0 & 0 & 0 & 112 & 0 & 0 \\
\hline Potamogeton schwenfurthii & 26 & 0 & 52 & 0 & 0 & 350 & 0 \\
\hline Spermacoce princiae & 0 & 51 & 0 & 0 & 0 & 0 & 0 \\
\hline Kalanchoe desiflora & 18 & 0 & 0 & 0 & 0 & 0 & 0 \\
\hline Ageratum conyzoides & 38 & 0 & 0 & 0 & 0 & 78 & 0 \\
\hline Microglossa densiflora & 0 & 0 & 20 & 0 & 0 & 0 & 0 \\
\hline Polygonum sp. & 0 & 0 & 30 & 0 & 0 & 0 & 0 \\
\hline Cyperus dives & 0 & 0 & 115 & 85 & 320 & 80 & 50 \\
\hline
\end{tabular}




\begin{tabular}{llllllll}
\hline Teramnus sp. & 0 & 0 & 0 & 0 & 20 & 0 & 0 \\
Dichrocephala sp. & 0 & 0 & 20 & 0 & 0 & 0 & 0 \\
Oxyanthus sp. & 0 & 260 & 0 & 0 & 0 & 0 & 0 \\
Cyperus sp. & 0 & 0 & 120 & 75 & 470 & 251 & 185 \\
Commelina sp. & 0 & 0 & 0 & 0 & 0 & 125 & 0 \\
Panicum sp. & 0 & 0 & 0 & 0 & 300 & 0 & 0 \\
Alchemilla sp. & 0 & 0 & 0 & 0 & 50 & 0 & 0 \\
Osmondia regalis & 0 & 0 & 0 & 0 & 92 & 0 & 0 \\
Dissotis sp. & 0 & 0 & 0 & 0 & 85 & 0 & 0 \\
\hline
\end{tabular}

In Sironga wetland, the macrophytes community were dominated by C. asiatica (20.02\%), followed by Digitaria abyssnica (7.3\%) and Poa annua (7\%). The wetland was dominantly composed of $C$. asiatica. This is more or less stable because the difference in dominance with the next dominance species is large, approximately 13\%. Six species namely; Crassula granukii, Coelachne africana, Poa annua, Digtitaria abyssinica and Isolepis fruitans had percentage composition of above $5 \%$ indicating that their distribution was significant while the rest were insignificant (Table 2).

Table 2: Densities of macrophytes in Sironga Wetland.

\begin{tabular}{llllll}
\hline Botanical name & Range & Mean & SD & Total & \% Composition \\
\hline Ludwiga abyssinica & 17 & 4.25 & 8.5 & 17 & 0.22 \\
Achyrospermum schimperi & 18 & 4.5 & 9 & 18 & 0.23 \\
Kalanchoe desiflora & 18 & 4.5 & 9 & 18 & 0.23 \\
Microglossa densiflora & 20 & 5 & 10 & 20 & 0.26 \\
Dichrocephala sp. & 20 & 5 & 10 & 20 & 0.26 \\
Blechum indicum & 12 & 5.5 & 6.4 & 22 & 0.28 \\
Pellaca vindis varocanonica & 22 & 5.5 & 11 & 22 & 0.28
\end{tabular}




\begin{tabular}{|c|c|c|c|c|c|}
\hline Polygonum sp. & 30 & 7.5 & 15 & 30 & 0.39 \\
\hline Athyrium filix-femina & 20 & 8.75 & 10.3 & 35 & 0.45 \\
\hline Alchemilla kiwawensis & 20 & 8.75 & 10.3 & 35 & 0.45 \\
\hline Polygonum salicifolium & 38 & 9.5 & 19 & 38 & 0.49 \\
\hline Ageratum conyzoides & 38 & 9.5 & 19 & 38 & 0.49 \\
\hline Sphaeranthus suaveolens & 45 & 11.25 & 22.5 & 45 & 0.58 \\
\hline Tristema mauritianum & 27 & 12.25 & 11.5 & 49 & 0.63 \\
\hline Spermacoce princiae & 51 & 12.75 & 25.5 & 51 & 0.66 \\
\hline Polygonum setosulum & 58 & 14.5 & 29 & 58 & 0.75 \\
\hline Aciotis acuminifolia & 50 & 15 & 23.8 & 60 & 0.77 \\
\hline Potamogeton schwenfurthii & 52 & 19.5 & 24.8 & 78 & 1.01 \\
\hline Robus apetalus & 120 & 30 & 60 & 120 & 1.55 \\
\hline Limnophila chinensis & 150 & 37.5 & 75 & 150 & 1.94 \\
\hline Panicum virgatum & 158 & 39.5 & 79 & 158 & 2.04 \\
\hline Pennisetum clandestinum & 185 & 46.25 & 92.5 & 185 & 2.39 \\
\hline Cyperus sp. & 120 & 48.75 & 59.2 & 195 & 2.52 \\
\hline Cyperus dives & 115 & 50 & 59 & 200 & 2.58 \\
\hline Oxyanthus sp. & 260 & 65 & 130 & 260 & 3.36 \\
\hline Cyperus rotundus & 150 & 66.25 & 77.8 & 265 & 3.42 \\
\hline Cyperus helferi & 254 & 88.5 & 119.9 & 354 & 4.57 \\
\hline Cyperus marginatus & 254 & 88.5 & 119.9 & 354 & 4.57 \\
\hline Comarum palustre & 210 & 90 & 106.7 & 360 & 4.65 \\
\hline Actinoscirpus grossus & 210 & 90 & 106.7 & 360 & 4.65 \\
\hline Crassula granuikii & 195 & 117.5 & 84.1 & 470 & 6.07 \\
\hline Isolepis fruitans & 57 & 118.75 & 24.4 & 475 & 6.13 \\
\hline Coelachne Africana & 320 & 132.5 & 159.4 & 530 & 6.84 \\
\hline Poa annua & 315 & 135.5 & 160.5 & 542 & 7.00 \\
\hline Digitaria abyssinica & 96 & 140.5 & 45.7 & 562 & 7.26 \\
\hline Centella asiatica & 650 & 387.5 & 301 & 1550 & 20.02 \\
\hline
\end{tabular}


In Kapkatet wetland, two species, C. helferi and C. asiatica were almost co-dominant, implying a relative instability in dominance, while other species such as C. marginatua and C. rotundus had a relatively high percentage composition. Eight species (C. marginutus, Cyperus sp., C. rotundus, Crassula granukii, C. asiatica, C. helferi, Actinoscirpus grossus and Comarun palustre) had percentage composition greater than $5 \%$ while the remaining species had low abundance of less than $5 \%$ (Table 3). Therefore, the two wetlands exhibited a clear difference in the dominant macrophyte community with Sironga being dominated by C. asiatica while Kapkatet wetland was dominated by C. helferi. Some macrophytes, such as C. asiatica and P. annua in Sironga wetland, and C. marginatus and C. asiatica in Kapkatet wetland, showed a high degree of variance in their spatial distributions. There were three lifeforms of aquatic macrophytes found in both Sironga and Kapaktet wetlands namely, emerged, submerged and floating, which were dominated by $C$. asciatica and Cyperus sp. There was only one floating macrophytes species in both wetlands, Potamogeton schwenfurthii. which was dominant in Kapaktet wetland.

Table 3: Densities of macrophytes within Kapkatet wetland.

\begin{tabular}{llllll}
\hline Botanical Name & Range & Mean & SD & Total & \% Composition \\
\hline Kolanchoe densiflora & 17 & 5.67 & 9.81 & 17 & 0.12 \\
Teramnus sp. & 20 & 6.67 & 11.55 & 20 & 0.14 \\
Blechum indicum & 22 & 7.33 & 12.70 & 22 & 0.15 \\
Athyrium filix- femina & 25 & 14.33 & 12.90 & 43 & 0.29 \\
Alchemilla sp. & 50 & 16.67 & 28.87 & 50 & 0.34 \\
Spermacoce princiae & 51 & 17.00 & 29.44 & 51 & 0.35 \\
Cyphostempm barbuseti & 62 & 20.67 & 35.80 & 62 & 0.42 \\
Polygonum nepalense & 66 & 22.00 & 38.11 & 66 & 0.45 \\
Achyrospermum schimperi & 75 & 25.00 & 43.30 & 75 & 0.51 \\
Ageratum conyzoides & 78 & 26.00 & 45.03 & 78 & 0.53
\end{tabular}




\begin{tabular}{|c|c|c|c|c|c|}
\hline Dissotis sp. & 85 & 28.33 & 49.07 & 85 & 0.58 \\
\hline Osmondia regalis & 92 & 30.67 & 53.12 & 92 & 0.62 \\
\hline Polygonum salicifolium & 112 & 37.33 & 64.66 & 112 & 0.76 \\
\hline Commelina diffusa & 118 & 39.33 & 68.13 & 118 & 0.80 \\
\hline Commelina sp. & 125 & 41.67 & 72.17 & 125 & 0.85 \\
\hline Colocasia esculenta & 150 & 50.00 & 86.60 & 150 & 1.01 \\
\hline Helichrysum globosum & 165 & 55.00 & 95.26 & 165 & 1.12 \\
\hline Ludwiga abyssinica & 167 & 55.67 & 96.42 & 167 & 1.13 \\
\hline Melanthera scandens & 185 & 61.67 & 106.81 & 185 & 1.25 \\
\hline Alchemilla kiwawensis & 171 & 77.67 & 86.57 & 233 & 1.58 \\
\hline Pennisetum clandestinum & 250 & 83.33 & 144.34 & 250 & 1.69 \\
\hline Plectrathus punctatus & 258 & 86.00 & 148.96 & 258 & 1.75 \\
\hline Dissotis senegambieceaesis & 298 & 99.33 & 172.05 & 298 & 2.02 \\
\hline Panicum sp. & 300 & 100.00 & 173.21 & 300 & 2.03 \\
\hline Robus apetalus & 350 & 116.67 & 202.07 & 350 & 2.37 \\
\hline Potamogeton schwenfurthii & 350 & 116.67 & 202.07 & 350 & 2.37 \\
\hline Helichrysum forskahlii & 392 & 130.67 & 226.32 & 392 & 2.65 \\
\hline Cyperus dives & $50-320$ & 150.00 & 147.99 & 450 & 3.04 \\
\hline Isolepis fruitans & $108-225$ & 151.00 & 64.37 & 453 & 3.07 \\
\hline Panicum virgatum & 372 & 164.00 & 189.86 & 492 & 3.33 \\
\hline Comarum palustre & 750 & 250.00 & 433.01 & 750 & 5.07 \\
\hline Actinoscirpus grossus & 750 & 250.00 & 433.01 & 750 & 5.07 \\
\hline Crassula granuikii & 558 & 257.67 & 281.44 & 773 & 5.23 \\
\hline Cyperus sp. & $185-470$ & 302.00 & 149.19 & 906 & 6.13 \\
\hline Cyperus rotundus & 750 & 356.67 & 376.34 & 1070 & 7.24 \\
\hline Cyperus marginatus & $138-1055$ & 481.00 & 500.24 & 1443 & 9.76 \\
\hline Centella asiatica & 200- 1050 & 583.33 & 431.08 & 1750 & 11.84 \\
\hline Cyperus helferi & $278-1100$ & 609.33 & 433.55 & 1828 & 12.37 \\
\hline
\end{tabular}


Shannon Weiner index (H), Simpson (1-D), Species Evenness and Richness were used in this study. Shannon Weinner ranged from 1.623 site T1 to 2.846 site S1 (Table 4). Shannon Weinner was highest in site S1 by 2.846 and lowest in site T1 by 1.623, Simpson ranged from 0.757 at site T1 to 0.926 in site S1. Simpson was highest in site S1 by 0.926 and lowest in site T1 by 0.757. Species Evenness ranged from 0.600 in site G1 to 0.898 in site S3. Evenness diversity index was highest in site S3 by 0.898 and lowest in site G1 by 0.60 . Species richness ranged from 0.726 in site S3 to 2.873 in site S1. Richness diversity was highest in site S1 by 2.873 and lowest in site S3 by 0.726 .

Table 4: Macrophytes diversity indices in Sironga and Kapkatet wetlands.

\begin{tabular}{lccccccc}
\hline & G1 & T1 & W1 & W2 & S1 & S2 & S3 \\
\hline Taxa (S) & 19 & 7 & 21 & 9 & 27 & 14 & 6 \\
Shannon (H) & 2.434 & 1.623 & 2.698 & 1.826 & 2.846 & 2.137 & 1.685 \\
Simpson (1-D) & 0.888 & 0.757 & 0.915 & 0.778 & 0.926 & 0.829 & 0.800 \\
Evenness & 0.600 & 0.724 & 0.707 & 0.690 & 0.638 & 0.605 & 0.898 \\
Richness & 2.448 & 0.927 & 2.478 & 1.087 & 2.873 & 1.578 & 0.726 \\
\hline
\end{tabular}

\section{DISCUSSION}

Lotic wetlands play a crucial role in the stream ecosystems by protecting the stream banks from the impacts of floods and storm waters, removing environmental pollutants and improve the water quality. These wetlands provide habitat for flora and fauna, hence enhancing the biodiversity of streams by supporting different life forms. Although the macrophyte community in both the two wetlands were represented by three biological forms, the emergent species 
dominated the wetlands while the floating macrophytes only occupied sheltered stream waters of Kapkatet wetland. Only few macrophytes were uniformly distributed across both the wetlands, and the abundance varied considerably based on anthropogenic activities and water quality parameters. Macrophytes diversity and species composition was high in both wetlands. The abundantly distributed macrophytes, such as Apiaceae, Cyperaceae, Poaceae and Cyperus sp. and the frequently occurring macrophytes, such as Plantaginaceae and Crassulaceae could be considered resilient and well-adapted to the changing wetland environment as a result of increasing anthropogenic activities, while Blechnaceae, Dyropteridae, Melastomataceae, Commelinaceae, Rosaceae, Melatomataceae, Potamogetanaceae, Onagraceae, Polygonaceae, Asteraceae and Rubiaceae were less abundant and rarely distributed, and could be highly vulnerable to environmental changes. The high abundance of Apiaceae, Cyperaceae, Poaceae and Cyperus sp. was attributed and correlated to high dissolved oxygen, total nitrogen and favourable temperatures at the sites. Four families of macrophytes were distributed in all sites of the Kapkatet wetland, Apiaceae, Blechnaceae, Plantaginaceae and Cyperaceae.

Macrophytes are highly sensitive to the environmental changes caused by natural and anthropogenic effects. In Sironga wetland, the highest number of macrophytes recorded at site W1 was attributed to exposure to sunlight, clear water and high nutrients level while the lower number recorded at site $\mathrm{T} 1$ was attributed to encroachment of the wetland, paddocking and agricultural activities. These activities have led to nearly total loss of a large number of macrophyte species which had been previously observed growing in the wetland. In contrast, the highest number of macrophytes recorded at site S1 in Kapkatet wetland, which would have been due to high levels of total nitrogen and phosphorus, resulting from inorganic fertilizers used in the adjacent farms which are known to promote the growth of aquatic plants. Nevertheless, some species such as Blechum indicum were directly lost from the riparian zone of 
Sironga wetland as a result of frequent use of pesticides for weeding, since the wetland is located within a high potential agricultural land [18].

However, lower abundance of macrophytes recorded at site S3 can be attributed to high turbidity, which prevents light penetration and consequently slowing the rate of photosynthesis. Both wetlands experienced related anthropogenic influences resulting from activities such as grazing, farming, infrastructural development, and replacement of indigenous vegetation with exotic trees which are known to lower the water table. Indeed, [7] had observed that a decreased water table could be the main reason for the decline in species richness of macrophytes. This is further supported by [19] who reported that decreased water table disturbs the microbial habitat and activity in the surface waters affecting the survival and growth of some macrophyte species. In addition, grazing defoliates the vegetation cover which alters the ecosystem interactions leaving only the most resilient plants. [20] found that paddocking can cause habitat fragmentations and alter the community structure of macrophyte species through disturbance of their ecological niches.

The abundance and dominance of the three families of macrophytes, Apiaceae, Cyperaceae and Poaceae in both wetlands was highly correlated to dissolved oxygen levels, total nitrogen, phosphorous and the prevailing optimum temperatures (unpublished data). Generally, the three families of emergent macrophytes (Apiaceae, Crassulaceae and Cyperaceae) dominated the macrophyte communities due to their competitive ability, which makes them able to survive in both aerobic and anaerobic conditions. [21] found that these species can recycle nutrients hence create energy flows, through microbial loops, which sustains them and various commensals which grow in association with these macrophytes. Their abundance can however be restricted by indiscriminate harvesting for livestock feed reducing the available biomass for 
primary consumers and decomposers and nutrient sequestration [22]. Consequently, the low abundances of Blechum indicum, Athyrium filix-femina, Actinoscirpus grossus, Robus apetalus, and Colocasia esculenta species at sites G1 and T1 could be largely attributed to increased human activities and therefore a possible loss of some ecological values of these wetlands. For instance, Cyperus species such as $C$. rotundus are important in phytoremediation because they accumulate heavy metals such as $\mathrm{Cr}, \mathrm{Mn}, \mathrm{Fe}, \mathrm{Cu}, \mathrm{Zn}$ and $\mathrm{Pb}$ [8]. Climate change has also exacerbated the effects of anthropogenic activities in the wetlands through by changing the reproduction cycles and growth patterns of macrophytes [23] and macrophyte densities of macrophytes showed a significant relationship with nutrient levels, particularly nitrates, phosphates and dissolved oxygen. Previous researchers such as [24] and [25] consider a high Shannon-Wiener diversity index $\left(\mathrm{H}^{\prime}\right)$ to be a good indicator of optimal water quality conditions for the survival and growth of macrophytes. In this study, the high macrophytes diversity at $\mathrm{S} 1\left(\mathrm{H}^{\prime}=2.846\right)$ in (Table 4$)$, indicates optimum temperature, nutrients availability and light penetration (unpublished data). High temperatures enhance the solubility rates of DO and increase the metabolic processes of the macrophytes. Comparatively, higher macrophyte species diversity was recorded during the rainy season (May, June and July) due to warmer temperatures and nutrients (unpublished data) influxes from overland. The Shannon's index which ranged 1 to 2.5 units indicated eutrophication in most sampling areas of the wetlands during the rainy seasons which was influenced by seasonal nutrient fluctuations. This trend was observed in site S1 which had had the highest species richness of 2.873. The low species richness recorded at S3 (0.726) could be due to poor environmental conditions, such as anoxic conditions which affected plant establishment and growth and the species evenness showing how the individuals are distributed within the wetland were closer to 1 . According to [26], values closer to 1 indicate high evenness in the distribution of species. The high species evenness recorded at S3 of 0.898 
can be attributed to evenness of the environmental conditions which favored survival of the plants all over the habitat. The low species evenness recorded at G1 of 0.60 indicates a shift to dominance where only few species dominate the station as a response to unfavorable conditions.

\section{Conclusion and Recommendations}

The diversity, distribution, and abundance of macrophytes was determined by water temperature, dissolved oxygen, TN, TP, TSS and turbidity (unpublished data) in both Sironga and Kapkatet wetlands. Various anthropogenic activities impact negatively and affected water quality and the diversity, distribution, and abundance of macrophytes species in both Sironga and Kapkatet wetlands, which include wetland conversion, poor farming practices, wetland encroachment, deforestation, and unsustainable exploitation of macrophytes which degrade macrophytes and deteriorate water quality. Roads and buildings have been constructed in the wetlands resulting to loss of habitats for growth of macrophytes. Nevertheless, the study has mostly considered taxonomic aspects of macrophytes relating it to abundance, distribution, and biodiversity. However, for effective conservation and management of these lotic wetlands a future related study is needed to focus on: effects of sedimentation resulting from unsustainable agricultural practices on water quality and macrophytes diversity, distribution, and abundance. Effects of changing land-use practices propagated by increased anthropogenic activities on these wetlands and how different environmental agencies can be involved in involved in the advocacy, conservation, and management of the riverine wetlands.

Acknowledgement: This study is part of the corresponding author's M. Sc. research. The authors are grateful to Kisii University and the African Development Bank (AfDB) for the financial and logistical support of this research and KMFRI for providing the laboratory space, materials and technical support during the study. 
Author Contributions Statement: Conceptualization, O.A., M.A; methodology, O.A., and A.J; validation, O.A., and M.A; formal analysis, M.D., O.J., and O.A; data curation, A.O.; writingoriginal draft preparation, O.J., O.A., M.A., and M.D

Conflicts of Interest Statement: The authors declare no conflict of interest.

\section{REFERENCES}

1. Bagalwa, M., Yalire, M., Balole, E., Karume, K. A Preliminary Assessment of PhysicoChemical and Bacteriological Characteristics of Lake Edward and Major Tributaries Rivers, Democratic Republic of Congo. Scholars Academic Journal of Biosciences (SAJB), 2014. 2(3): 236-245

2. Kasangaki, A., Champan, L.J.; Balirwa, J. Land use and the Ecology of Benthic Macroinvertebrate Assemblages of high-altitude rainforest Streams in Uganda. Freshwater Biology, 2008. 53: 681-697

3. Nyakeya, K., Raburu P.O., Masese, F., Gichuki, J. Assessment of pollution impacts on the ecological integrity of the Kisian and Kisat rivers in Lake Victoria drainage basin, Kenya. African Journal of Environmental Science and Technology, 2009. Vol. 3 (4), pp. 097-107.

4. Keche, A., Ochieng, G., Lekapana, P., Macharia, G. Status of wetlands in Kenya and Implications for sustainable development, 2011. Pp.16 pdf accessed on 19/2/19.

5. Mugo, M.J. Seasonal changes in physic-chemical status and Algal Biomas of Lake Naivasha, Kenya, (Msc. Thesis), 2010. pg. 1-122.

6. Venkatesharaju, K., Ravikumar, P., Somashekar, R.K., Prakash, K.L. Physicochemical and bacteriological investigation on the river Cauvery of Kollegal stretch in Karnataka. Kathmandu University Journal of Science, Engineering and Technology, 2010. 6(1) 50-59.

7. Mutyavaviri, F. Impact of cultivation on soil and species composition of the Monavale, African Journal of Environmental Science and Technology, 2006.

8. Chatterjee, S., Chetia, M., Singh, L., Chattopadhyay, B., Datta, S., Mukhopadhyay, S.K. A study of the phytoaccumulation of waste elements in wetland plants of a Ramsar site in India, Environ MOWE, 2011. Assess 178:361 -371.

9. Bobbink, R., Beltman, B., Whigham, D., Verhoeven, J. Wetland Functioning in Non-Point pollution of surface waters with phosphorous and nitrogen. Ecological society of America; 2011, pp. 8(3):559-568.

10. Mustapha, M.K., Omotosho, J.S. An assessment of the Physico- Chemical properties of Moro Lake, Kwara State, Nigeria. African J. of App. Zoo. and Envt. Bio, 2010. 7: 3-77. 
11. Sangpal, R.R., Kulkarni, U.D., Nandurkar, Y.M. An assessment of the physico-chemical properties to study the pollution potential of Ujjani Reservoir, Solapur District, India. ARPN Journal of Agricultural and Biological Science, 2011. VOL. 6, NO. 3, $34-38$.

12. Ojutiku, R.O., Koloanda, R.J. Temporal and spatial variations in some physico-chemical parameters of River Chanchaga, Niger State, Nigeria. Journal of Applied Biosciences, 2011. 47: 3242- 32455.

13. Deepak, S., Singh, N.U. The Relationship between Physico-chemical Characteristics and Fish Production of Mod Sagar Reservoir of Jhabua District, MP, India. Research Journal of Recent Sciences, 2014. Vol. 3, 82-86

14. Osumba, J., Okeyo-Owuor, J.B.; Raburu, P.O. Effect of harvesting on temporal papyrus (Cyperus papyrus) biomass regeneration potential among swamps in Winam Gulf wetlands of Lake Victoria Basin, Kenya. Wetlands Ecology and Management, 2010. 18: 333-341.

15. Sitenei, A., Jiwen, G.E., Mupenzi, J. Impacts of Anthropogenic Activities and Climate on Wetland Ecology: Case of Sitatunga (Tragelaphus Spekei) at Kingwal Wetland, Kenya, East African Journal of Science and Technology; 2011. 1(1):1- 8.

16. Sidinei, T., Cunha, E. The role of macrophytes in habitat structuring in aquatic ecosystem: Methods of measurements, causes and consequences on animal assemblages' composition and biodiversity. Acta Limnologica Brasiliensia, 2010 (22) .218-236. 10.4322/actalb.02202011.

17. Omondi, A.O., Ogendi, G.M., Onchieku, M.J., Oduor, S.O., Omondi, R., Omweno J.O. Phytoplankton community structure and ecology in Lake Naivasha, Kenya International Journal of Fisheries and Aquatic Studies, 2020. 8(3): 478-483

18. Nyagwansa, R., Ochola, W., Odhiambo, J., Bunyatta, D.; Omweno, J.O. Effectiveness of Selected Advisory Channels on Safe Use of Pesticides among the Small Holder Kale Farmers. A case of Kisii County, Kenya. East African Journal of Agriculture and Life Sciences, 2021. 4(6):151-156. DOI: 10.36349/easjals.2021.v04i06.003

19. Zedler, J.B., Kercher, S. Wetlands resources: status, trends, ecosystem services, and restorability, Annual Review of Environment and Resources; 2008. 30:39-74.

20. Trama, F.A., Patron, F.I., Kumar, A., Gonzalalez, E.; Somma, D., McCoy-C, M.B. Wetland cover types and plant community changes in response to cattail control activities in Palo Verde Marsh, Costa Rica Ecological Restoration, 2009; 27(20):278- 289.

21. Brix, H. Function of macrophytes in a constructed wetland. Coastal Area. Journal of Coastal Research, 2014; 27 (6): 1029-1051. 
22. Carpenter, S., Stanley, E., Vander, Z.J. State of the World's Freshwater Ecosystem: Physical, Chemical and Biological changes. Annual Review of Environment and Resources, 2012; 36.10.1146/annurev-environ-021810-094524.

23. Chambers, P.A.; Lacoul, P.; Murphy, K.J.; Thomaz, S.M. Global diversity of aquatic macrophytes in freshwater. Hydrobiologia, 2010; Vol., 595, No. 1, p. 9-26.

24. Ogendi, G.M., Getabu, A.M., Onchieku, J.M., Babu, J.M. Assessment of the microbial load at Nyanchwa-Riana. International journal of fisheries and Aquatic studies, 2015; 2(6): $182-$ 192.

25. Sitoki, L., Kurmayer, R., Rott, E. Spatial variation of phytoplankton composition, bio volume, and resulting microcystin concentrations in the Nyanza Gulf (Lake Victoria, Kenya), Hydrobiologia, 2012; 691:109-122

26. Dar, N.A., Pandit, A.K. and Ganai, B.A. Factors affecting the distribution patterns of aquatic macrophytes, Limnological Review, 2014; 14: 75-81.

C 2022 by the authors. Submitted for possible open access publication under the terms and conditions of the Creative Commons Attribution (CC BY) license (http://creativecommons.org/licenses/by/4.0/). 